\title{
DAKWAH DAN PEMBAHARUAN PEMAHAMAN ISLAM
}

\author{
Akhirudin \\ Dosen Komunikasi dan Penyiaran Islam (KPI) \\ Fakultas Agama Islam Universitas Islam Attahiriyah \\ Email: akhirudindc@gmail.com
}

\begin{abstract}
Change is the intrinsic nature of society. There is no society without change. He departed the change of mind of the human being who became members of the society. The development of science and technology has spurred the changes. Such changes also suggest changing the religious understanding. In assessing the various changes should da'wah make efforts to renew the understanding of Islam. With Da'wah and Renewal of Understanding of Islam discussed what steps taken by a da'i in the face of the change. In this connection a preacher should really understand the essence of Islamic teachings from the main source of the Qur' an and Sunnah Sahihah and then understand adequately the developments that occur due to the advance of modern science and technology. From these two forms of understanding da'i must be able to provide answers to the needs of the mad'u community who thirst for explanation when they face new problems in daily life that must get a reference from the Qur'an and Sunnah.
\end{abstract}

Keywords: Islamic Da'wah, Renewal, Understanding Islam

Abstrak: Perubahan adalah sifat instrinsik dari masyarakat. Tidak ada masyarakat tanpa perubahan. Ia bertolak perubahan alam pikiran manusia yang menjadi anggota masyrakat itu. Perkembangan sains dan teknologi telah memacu berbagai perubahan itu. Perubahan tersebut mengandaikan pula perubahan pemahaman keagamaan. Dalam mengkases berbagai perubahan tersebut haruskah dakwah melalukan upaya pembaharuan pemahaman Islam. Dengan Dakwah dan Pembaharuan Pemahaman Islam diperbicangkan langkah apa yang ditempuh oleh seorang da'i dalam menghadapi perubahan tersebut. Dalam kaitan ini seorang da'i harus memehami betul esensi ajaran Islam dari sumber utamanya Al-Qur'an dan Sunnah Sahihah dan kemudian memahami secara memadai perkembangan yang terjadi akibat kemajuan sains dan teknologi modern. Dari kedua bentuk pemahaman tersebut da'i harus mampu memberikan jawaban terhadap kebutuhan masyarakat mad'u yang haus akan penjelasan ketika mereka menghadapi problema-problema baru dalam kehidupan sehari-hari yang harus mendapat rujukan dari AlQur'an dan Sunnah.

Kata kunci: Dakwah Islam, Pembaharuan, Pemahaman Islam 


\section{Pendahuluan}

Dinamika dan adu kekuatan antara pembaharuan konservatif (yang selalu menengok Islam ke masa lalu) dan pembaharuan progresif (yang ingin merekonstruksi Islam untuk masa depan) merupakan agenda laten umat Islam sepanjang sejarah. Gerakan pembaharuan Islam yang biasa di sebut tajdid sebenarnya memiliki dasar kuat pada warisan pengalaman sejarah kaum muslim.

Tajdid merupakan salah satu bentuk implementasi ajaran Islam setelah nabi wafat. Oleh karena itu, tajdid merupakan tema yang sebenarnya sudah lama ada dalam dimensi kehidupan kaum muslim di dunia Islam. Dan kenyataannya, gerakan tajdid muncul dalam bentuk beragam, ${ }^{1}$ yang masing-masing mencerminkan jawaban kaum muslim terhadap persoalan yang mereka hadapi dalam waktu dan tempat tertentu.

Dalam sejarah tercatat bahwa pada masa kejayaan Islam pernah terjadi pembaharuan pemikiran dari pola tradisional-konservatif ke pola rasional modern $^{2}$ sebagaimana dilakukan oleh aliran Mu'tazilah sebagai respons terhadap perkembangan budaya dan sosial yang ada ketika itu. Perubahan pola pemikiran tadi, terjadi setelah ulama-ulama yang ada pada masa Abbasiyah berkenalan dengan filsafat Yunani. ${ }^{3}$

Sebenarnya pembaharuan itu sudah dilakukan jauh sebelum berkembangnyaaliran-aliran dalam Islam, tepatnyadi masaUmarbin Khattab yang banyak menggunakan ijtihadnya dalam merespons perkembangan zaman di masa itu. Untuk itu Umar dikenal sebagai pembaharuan pertama dalam Islam, walaupun sebagian ulama tidak mencamtumkannya dalam deretan mujaddid. Ini desebabkan Umar tidak termasuk dalam acuan periodesasi mujaddid, yang terbentur dengan interpretasi hadist Nabi ála ra'si kulli miáti sanatin (setiap awal abad), di mana Umar tentunya tidak

\footnotetext{
${ }^{1}$ Keberagaman bentuknya muncul dengan beberapa predikat seperti reformisme, modernisme, puritanisme, revivalisme, bahkan fundamentalisme. Adanya predikat yang berbeda-beda ini, disebabkan perbedaan sudut pandang dalam memposisikan gerakan pembaharuan itu sendiri, sehingga tidak heran, keberagaman gerakan itu dikarenakan keberagaman misi yang dibawa tiap-tiap gerakan pembaharuan tersebut dengan masing-masing pembaharunya.

${ }^{2}$ H.L. Beek dan N.J.G Kaptien (red), Pandangan Barat terhadap Literatun Hukum, Filosofot, Teologi, dan Mistik Tradisi Islam, Jakarta, INIS, 1998, h. 55

${ }^{3}$ P.Sj. van Koningsvela, Naskah-Naskah Yunani tentang Bait al-Hikmah dan Kebijakan Khalifah al-Ma'mun dalam Herman Leonard Beek dan Niro Kaptein (Red) Studi Belanda Kontemporer tentang Islam, Jakarta: INIS, 1993, h. 49-50
} 
masuk dalam kategori mujaddid yang lahir atau hidup pada awal abad sejak wafatnya Rasullulah.

Dalam perkembangan selanjutnya, sesuai pernyataan di awal tulisan ini, bahwa pembaharuan atau tajdid mengemban misi ganda (duo mission), yakni pertama, upaya mengimplementasikan ajaran Islam sesuai dengan tantangan perkembangan kehidupan. Kedua, mengembalikan semua bentuk kehidupan keagamaan pada contoh zaman awal Islam (pristine). Yang pertama biasa di sebut pembaruan, dan yang kedua biasa di sebut pemurnian.

\section{Arti Pembaharuan dan Latar Belakangnya}

Secara bahasa pembaharuan berasal dari kata baharu adalah sesuatu yang sebelumnya tidak ada. Dan pembaharuan dalam persepektif Islam adalah sesuatu yang berkaitan dengan Islam yang dulunya tidak ada. Sedangkan pemurnian berarti asli atau semula, di mana dalam Islam pemurnian adalah usaha mengembalikan seperti keadaan semula. ${ }^{4}$

Kata modernisasi atau modernisme merupakan serapan dari dunia barat yang berarti pembaharuan. Dalam masyarakat Barat menurut Harun Nasution Pembaruan adalah fikiran, aliran, gerakan, dan usaha-usaha untuk mengubah faham-faham dan adat istiadat, instuisi-instuisi lama dan lain-lain untuk disesuaikan dengan perkembangan zaman dan fahamfaham baru yang terjadi akibat perkembangan dan teknologi modern. ${ }^{5}$ Dan untuk memudahkan pembahasan, maka istilah pembaharuan, tajdid, dan modernisasi atau modernisme dijadikan dalam satu arti.

Rifyal ka'bah, mendefinisikan pembaharuan yang olehnya disebut pembaruan visi modernis_sebagai melihat Islam sejalan dengan semangat zaman modern. Hal-hal yang bertentangan dengan norma-norma Islam harus dilihat dari keyakinan, tidak ada pertentangan antara ajaran Islam dan akal atau logika, atau di artikan sebagai penafsiran kembali prinsipprinsip Islam yang nampak tidak sejalan dengan semangat zaman. ${ }^{6}$

\footnotetext{
4 Bustami Muhammad Sa'id, Gerakan Pembaharuan Agama Antara Modernisme dan Tajdiduddin, Bekasi PT. Wacanalazuardi, 1995, h. 29

${ }^{5}$ Harun Nasution, Pembaharuan dalam Islam Syarah Pemikiran dan Gerakan, Jakarta, Bulan Bintang, 1991, cet ke-8, h. 11

${ }^{6}$ Rifyal Ka'bah, Modernisme dan Fundamentalisme ditinjau dari konteks islam, dalam Jurnal Ilmu dan Kebudayaan Ulumul Qur'an, No. 3, Volume VI, 1998, h. 29
} 
Kedua definisi di atas, condong kepada makna pembaruan yang progresivis, artinya ingin merekonstruksi Islam ke masa depan, sesuai dengan perkembangan situasi dan zaman. Di samping itu, berbeda dengan pembaharuan yang diartikan sebagai permunian. Busthami Muhammad Sa'id, mendefinisikan pemurnian yang ia sebut sebagai pendapat al-Salaf al-Shalih adalah:

"Setiap usaha yang mendekatkan antara realitas masyarakat muslim di setiap zaman dengan masyarakat percontohan pertama, yang langsung dibina oleh Rasullulah saw. yaitu dengan menghidupkan pemahaman-pemahaman konsepsi-konsepsi masyarakat pertama tentang agama, menghidupkan manhajnya dalam membukukan ilmu dan bentuk system kehidupan, serta mengambil manfaat yang baik dari semua peradaban, dengan meluruskan penyelewengan pandangan, pemikiran, amaliyah, dan akhlak, juga menyucikan masyarakat dari semua kotoran."7

Definisi senada juga di kemukakan Rifyal Ka'bah sebagai pembaharuan visi salaf, yang berarti kembali kepada kemurnian (pemahaman) ajaran Islam seperti tercantum al-Qur'an dan as-Sunnah (pemahaman asli), seperti di contohkan Nabi Muhammad SAW dan para salaf yang saleh. Namun pendukung gerakan pemurnian ini sebagian-nantinya karena memperlihatkan wajah Islam yang keras sering mendapat cap fundamentalis. ${ }^{8}$

Dua pendapat terakhir, menunjukkan perbedaan antara pembaharuan progesif yang berorientasi ke masa depan dan pembaruan konservatif (pemurnian) yang orientasinya menuju awal Islam atau Islam sejati (pristine Islam).

Adapum latar belakang yang mendorong timbulnya pembaharuan paling tidak ada empat poin', yaitu:

Pertama, paham tauhid yang dianut kaum muslimin telah bercampur dengan kebiasaan-kebiasaan yang di pengaruhi oleh tarekat-tarekat,

\footnotetext{
${ }^{7}$ Bustami Muhammad Sa'id, Gerakan Pembaharuan Agama Antara Modernisme dan Tajdiduddin, Bekasi PT. Wacanalazuardi, 1995, h. 323

${ }^{8}$ Rifyal Ka'bah, Modernisme dan Fundamentalisme ditinjau dari konteks islam, dalam Jurnal Ilmu dan Kebudayaan Ulumul Qur'an, No. 3, Volume VI, 1998, h. 29

${ }^{9}$ Yusran Asmuni, Pengantar Studi Pemikiran dan Gerakan Pembaharuan Dalam Dunia Islam, Jakarta PT. Rajagrafindo Persada, 1998, Cet. Ke-2 h. 7
} 
pemujaan terhadap orang-orang suci dan hal lain yang membawa kepada kekufuran. ${ }^{10}$

Kedua, sifat jumud membuat ummat Islam berhenti berpikir dan berusaha, ummat Islam maju di zaman klasik karena mereka mementingkan ilmu pengetahuan, oleh karena itu selama ummat Islam masih bersifat jumud dan tidak mau berpikir untuk berijtihad, tidak mungkin mengalami kemajuan, untuk itu perlu adanya pembaharuan yang berusaha memberantas kejumudan.

Ketiga, ummat Islam selalu berpecah belah, maka ummat Islam tidaklah akan mengalami kemajuan. Ummat Islam maju karena adanya persatuan dan kesatuan, karena adanya persaudaraan yang diikat oleh tali ajaran Islam. Maka untuk mempersatukan kembali ummat Islam bangkitlah suatu pembaharuan.

Keempat, hasil kontak yang terjadi antara dunia Islam dengan Barat. Dengan adanya kontak ini ummat Islam sadar bahwa mereka mengalami kemunduran di bandingkan dengan Barat, dalam hal ini terutama dalam hal kekuatan militer modern yang di miliki Barat (Eropa).

Pembaharuan dalam Islam tejadi bukan disebabkan terjadinya pertentangan antara kaum agama dan ilmuan sebagaimana terjadi dengan Renaisans Barat dimana pembaharuan di dalamnya dalam rangka menyingkirkan agama melainkan karena adanya kesadaran di kalangan tokoh-tokoh pembaharuan akan keterbelakangan umat Islam dari dunia Barat. Pada masa Barat sedang dalam kemajuan ilmu yang tinggi, dunia Islam justru sebaliknya bahkan hampir semua dunia Islam berada di bawah level dunia Barat. Di samping itu pembaruan juga merupakan upaya prinsip-prinsip dan ajaran-ajaran Islam kepada pemeluknya.

Menyadari hal itu, tokoh-tokoh seperti Jamaluddin al-Afghani, Muhammad Abduh, dan lain-lain tampil menyerukan umat Islam agar menyadari jati dirinya selaku umat yang pernah jaya di muka bumi ini. Maka lahirlah dari tokoh pembaruan seperti gagasan cinta tanah air (Rifat Badawi Rafi al-Tahwi), anti imprealisme (Jamaluddin al-Afghani), rasionalisme Mu'tazilah (Muhammad Abduh), rekonsepsi bentuk pemerintahan Islam

${ }^{10}$ Di sini jelas makna pemurnian (purifikasi) yaitu untuk memperbaiki akidah dan ibadah yang telah terkontaminasi dengan budaya dan zaman. Terutama terhadap penyelewengan dan bid'ah, baik penyelewengan yang muncul dan faktor-faktor intern masyarakat muslim maupun dan intrikintrik jahat dari luar. 
(Ali Abdul Raziq), dan lain-lain. ${ }^{11}$ Tokoh-tokoh pembaharuan tadi pada prinsipnya mengajak umat Islam untuk bangkit dari tidur lelapnya agar bisa melepaskan diri dari kungkungan keterbelakangan dan tekanan penjajah.

Dari sini jelas bahwa latar belakang terjadinya gerakan pembaharuan dalam Islam bukan akibat adanya pertentangan kaum agama dan kaum ilmuan sebagaimana terjadi pada Kristen, melainkan karena adanya perasaan tertinggal dari dunia Barat. Hali ini bisa difahami dari kekaguman Muhammad al-Jabarti ${ }^{12}$, Rifah Badawi Rafi' al-Tahtawi dan Khair al-Din Tunisi ${ }^{13}$ atas kemajuan-kemajuan yang di capai bangsa Barat. Rasa kagum mereka terekspresi pada saat mengunjungi kajian ilmu yang di bawa bangsa Perancis pada masa ekspidisi Napoleon di Mesir.

\section{Macam-macam pembaharuan}

Tujuan dari pembaharuan itu tidak lain adalah untuk menciptakan yang baik untuk umat Islam. Untuk itu pembaharuan merupakan dimensi penting dalam pengalaman sejarah umat Islam. Karena itu, dalam rangka gerakan ini, aspek yang penting menjadi misi umat Islam, tidak lain adalah mengimplementasikan ajaran Islam dalam kondisi aktual dalam kehidupan masyarakat, dan mencoba mereflesikan ciri dasar ajaran Islam tersebut. Dan hal ini jelas terlihat dalam slogan yang bukan hanya mengajak kembali kepada al-Qur'an dan al-Sunnah tetapi juga klaim akan perlunya ijtihad (pembaharuan).

Adapun lapangan pembaharuan adalah:

1. Pembaharuan dalam masalah keagamaan

Pemurnian dalam masalah keagamaan berusaha semaksimal mungkin untuk menghidupkan Islam yang suci dan bersih dari kejelekan masa lalu, dari bentuk penyelewengan, dan hawa nafsu manusia serta kejahilannya. Ruang lingkup pemurnian biasanya mencakup bidang aqidah (ketauhidan) dan ibadah. Gerakan pemurnian ini dipelopori oleh Muhammad bin Abdul Wahab.

${ }^{11}$ John J. Donohue dan John L. Esposito. Islam dan Pembaharuan: Ensiklopedi MasalahMaslah, Jakarta: PT. Rajawali Press, 1984, h. 7-39

${ }^{12}$ Harun Nasution dan Azyumardi Azra, Perkembangan Modern Dalam islam, Jakarta: Obor, 1986, h. 31

${ }^{13}$ Acmad jainuri, landasan Teologis Gerakan Pembaharuan Islam dalam Jurnal Ulumul Qur'an No. 3. Volume VI, tahun 1995 
2. Pembaharuan dalam masalah sosial kemasyarakatan (mu'amalah)

Banyak sekali malah seputar sosial kemasyarakatan apabila dibicarakan keseluruhan. Pembaharuan dalam konteks ini diartikan sebagai penafsiran kembali beberapa prinsip Islam yang nampak tidak sejalan dengan semangat zaman. Prinsip-prinsip tersebut, misalnya, tentang emansipasi wanita, baik dalam karir maupun pendidikan, masalah riba, hukuman hudud, minuman keras, prinsip syura, jihad, persatuan agama dengan negara lain-lain. ${ }^{14}$

3. Pembaharuan dalam masalah politik

Masalah politik tidak lepas dengan masalah bernegara. Sehingga kemajuan suatu negara tidak lain dilihat bagaimana kebijakan dan kondisi negara tersebut dalam menyikapi perkembangan zaman, sehingga dapat melahirkan suatu kekuatan dalam bernegara. Ide-ide pembaharuan politik antara lain di suarakan Ibnu Tamiyyah yang menginginkan superioritas syaria’at dalam negara dan ide-ide politiknya yang lain.

\section{Obyek Pembaharuan}

Lapangan yang dimaksud adalah perihal apa saja yang dapat di perbaharui. Harun Nasution mengatakan, "kalau mau mengadakan pembaharuan dalam Islam, kita mesti mengadakan pembedaan pokok antara ajaran yang qathriy dan dhanny, perlu di bedakan dulu ajaran yang absolut dengan yang relatif. itu kuncinya." ${ }^{15}$

Distingsi antara qathizy (yang absolut) dan dhanny (yang relatif), tampaknya begitu penting bagi Harun Nasution, karena di sinilah anggapannya diletakkan ruang untuk ijtihad. Itulah sebabnya, walaupun al Qur'an secara keseluruhan adalah qath'iy al-wurud (absolut benar dari Allah), tapi oleh ulama dibedakan antara, ayat-ayat yang jelas (keterangan yang pasti), absolut dan satu artinya (qathiy al-dalalah), dan ayat bisa mengandung berbagai pengertian (zhannry al-dalalah) yang keterangannya menunjukkan ketidakpastian. Ayat-ayat dhanniy al-dalalah inilah yang me-

\footnotetext{
${ }^{14}$ Rifyal Ka'bah, Modernisme dan Fundamentalisme ditinjau dari konteks islam, dalam Jurnal Ilmu dan Kebudayaan Ulumul Qur'an, No. 3, Volume VI, 1998, h. 29

${ }^{15}$ Lihat, Refleksi Pembaharuan Pemikiran Islam: 70 Tahun Harun Nasution, Jakarta, LSAF, pada bagian biografi Harun Nasution
} 
nimbulkan berbagai mazhab dan aliran dalam Islam, dimana tafsiran dari ayat-ayat yang dhanniy al-dalalah inilah yang menjadi obyek pembaharuan.

Dengan demikian, dapat dikatakan bahwa pembaharuan dalam Islam tidak menyangkut ayat-ayat al-Qur'an yang qath'iy al-dalalah dan hadits mutawatir melainkan menyangkut penafsiran ayat-ayat yang dhanniy aldalalah dan hadits yang bukan mutawatir tadi.

\section{Dakwah dan Pembaharuan Pemahaman Islam}

Aturan (hukum) yang mengatur urusan aqidah maupun ibadah (hablum minallah) telah begitu jelas (al-Qur'an dan as-Sunnah). Manusia tidak memiliki wewenang untuk ikut rembug membuat aturan lagi sekalipun ia seorang cendekiawan atau ulama terkenal, baik dengan cara menambah atau menguranginya. Berbeda halnya dengan urusan mu'amalah atau kemasyarakatan (hablum minannas), manusia diberi otoritas secara teknis untuk mengatur sendiri sepanjang tidak ada larangan dari Allah SWT dan Rasul-Nya.

Berangkat dari paparan di atas, penulis mencoba mengakses berbagai perubahan yang berkaitan dengan perkembangan sains dan teknologi atau yang berkaitan dengan mu'amalah dan kaitannya dengan dakwah melakukan upaya pembaharuan pemahaman Islam. Namun penulis tidak punya keberanian untuk menjelaskan masalah-masalah di atas dengan alasan; berijtihad dalam berbagai masalah ada syarat-syaratnya. Tidak setiap orang berhak untuk memberi fatwa dan berbicara tentang berbagai masalah kecuali berdasarkan ilmu dan menguasainya, mampu mengetahui dalil-dalilnya, baik berupa nash maupun realita, yang shahih dan dhaif (lemah), nasikh (penghapus) dan mansukh (terhapus), mantuq (tersurat) dan mafhum (tersirat), khusus dan umum, mutlaq dan terikat, yang global dan terperinci. Di samping itu, harus melalui pengkajian yang matang, mengetahui pembagian-pembagian fikih dan topik-topik bahasan, juga pendapat-pendapat ulama dan fuqaha serta hafal nash-nash dan memahaminya. ${ }^{16}$

Tidak diragukan lagi, bahwa pengacauan fatwa tanpa penguasaan adalah dosa besar, juga berbicara tanpa berdasarkan ilmu. Allah SWT telah menyerukan:

${ }^{16}$ Khalid Al-Juraisiy, Fatwa-fatwa Terkini 2, Jakarta: Darul Haq, 2004, h. 217 


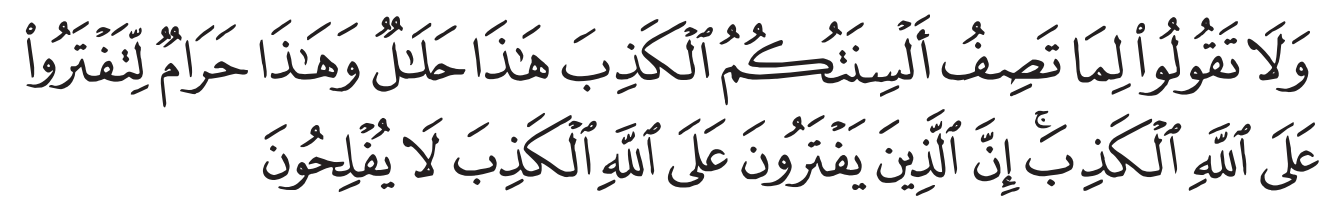

Dan janganlah kamu mengatakan terhadap apa yang disebut-sebut oleh lidahmu secara dusta "ini halal dan ini haram", untuk mengada-adakan kebohongan terhadap Allah. Sesungguhnya orang-orang yang mengadaadakan kebohongan terhadap Allah tiadalah beruntung. (QS. al-Nahl: 116).

Dalam hadits pun disebutkan:

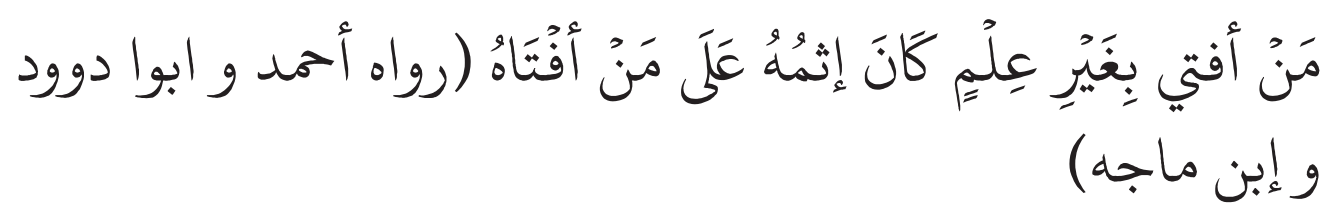

Barangsiapa diberi fatwa yang tidak berdasarkan ilmu, maka dosanya menjadi tanggungan yang memberi fatwa. (HR. Ahmad, Abu Dawud dan Ibn Majah)

Dari kekhawatiran akan terjerumus ke dalam ijtihad (pembaharuan) yang salah itulah penulis menukil fatwa-fatwa terkini oleh Syaikh Abdul Aziz bin Abdullah bin Baz, Syaikh Muhammad bin Shalih Al-Utsaimin, Syaikh Abdullah bin Abdurrahman Al-Jibrin, Syaikh Shalih bin Fauzan AlFauzan dan Lajnah Da'imah lil Buhuts Al-Ilmiah wal Ifta' (komite tetap kajian ilmiah dan pemberian fatwa) dan Fatwa-fatwa Jual Beli oleh Ulamaulama Besar Terkemuka, sebagai berikut:

1. Kartu yang dikeluarkan beberapa perusahaan untuk mempermudah transaksi di pasar ${ }^{17}$

\section{Pertanyaan:}

Di Amerika terdapat semacam transaksi antara orang-orang yang ikut tergabung dalam transaksi sebagai pihak pertama, dan perusahaan penyelenggara sebagai pihak kedua. Transaksi ini berisi:

a Perusahaan akan mengeluarkan kartu yang memuat nomor dan nama peserta, di mana seseorang dapat menggunakan kartu ini di berbagai tempat bisnis (merchant) untuk membayar barang yang dibeli. Demikian juga untuk pembayaran di rumah makan

${ }^{17}$ Ahmad bin 'Abdurrazzaq ad-Duwaisy, Fatwa-fatwa Jual Beli oleh Ulama-ulama Besar Terkemuka, (Bogor: Pustaka Imam Syafi'I, 2004), h. 533 
dan hotel. Juga bisa untuk membeli tiket pesawat dari perusahaan penerbangan, dan lain-lain. Selanjutnya, pihak yang menarik bayaran yang memakai kartu ini akan mengirimkan rincian tagihan ke perusahaan yang mengeluarkan kartu tersebut, untuk kemudian membayarkan tagihan bagi pemegang kartu.

b Pada akhir bulan, perusahaan yang mengeluarkan kartu ini akan memberikan laporan kepada pemegang kartu dan meminta darinya untuk membayar seluruh tagihan yang harus dia bayar selama satu bulan dan juga tagihan yang dibayarkan oleh perusahaan kepada pemilik tempat-tempat perdagangan.

c Perusahaan yang mengeluarkan kartu juga meminta kepada pemegang kartu untuk membayar tagihan yang harus dia bayarkan selama 1 bulan berlangsung dalam masa maksimal 15 hari dari tanggal pengiriman faktur tagihan. Jika dia tidak membayar selama masa 15 hari tersebut, maka pihak perusahaan akan mengirimkan faktur tagihan untuk yang kedua kali dengan tagihan yang sama dan yang belum dilunasinya dengan tambahan nilai 10 dolar, sebagai denda keterlambatan. Dan jika setelah pegiriman faktur yang kedua ini pemegang kartu belum melunasinya, maka pihak perusahaan akan mengirimkan faktur untuk yang ketiga dan terakhir kalinya, serta meminta kepadanya supaya melunasi tagihannya dengan tambahan senilai 2,5 dari dana tagihan sebagai denda keterlambatan, sebagaimana perusahaan juga akan membatalkan perjanjian dan menarik kartu dalam keadaan ini.

d Masa perjanjian itu berlangsung selama setahun. Bagi pemegang kartu harus membayar iuran tahunan sebesar 30 dolar sebagai biaya keikutsertaan dan penerbitan kartu untuknya.

e Pembayaran atas faktur yang dikirimkan itu dalam bentuk mata uang Amerika (dolar). Jika seorang pemegang kartu menggunakan kartu di luar Amerika, maka perusahaan akan mengirimkan faktur tagihan dalam bentuk mata uang Amerika. Hal itu dengan cara memindahkan nilai tagihan dalam bentuk mata uang negara lain ke dalam mata uang Amerika (dolar). Dan nilai tukar yang digunakan adalah nilai tukar pada hari dikirimkannya faktur tagihan kepadanya, bukan dengan nilai tukar pada hari digunakannya kartu untuk pembelian di luar Amerika. Dan perusahan juga 
meminta supaya pemegang kartu membayar tagihan dengan dolar dengan tambahan yang nilainya $1 \%$, sebagai ongkos transfer dan penukaran mata uang.

f. Bagi masing-masing pihak boleh membatalkan akad kapan pun setelah adanya pemberitahuan dari pihak yang akan membatalkan.

Kami mengharap kemurahan hati anda untuk menjawab pertanyaan berikut ini: Apakah akad ini boleh atau tidak? Jika boleh bagi orang muslim untuk ikut serta dalam akad ini, kami mengharapkan penjelasan spesifikasi akad ini dan sebab-sebab kebolehannya. Dan apakah ia merupakan akad perwakilan, jaminan atau sewa menyewa antara seseorang dengan perusahaan yang mengeluarkan kartu? Dan jika tidak boleh, kami tetap mengharapkan penjelaskan mengenai sebab yang menjadikan akad itu gugur dan batal.

\section{Jawaban:}

Jika masalahnya seperti yang disebutkan di atas, maka tambahan yang diambil perusahaan merupakan salah satu bentuk riba, sehingga tidak diperbolehkan untuk mengambilnya, karena riba itu diharamkan berdasarkan al-Qur'an, as-Sunnah dan Ijma'. Akad ini jika tanpa bunga, maka ia termasuk akad jaminan. Dan jika memakai bunga saat pemegang kartu melakukan keterlambatan, maka akad tersebut tidak diperbolehkan.

Demikian juga dengan pembayaran tahunan 30 dolar untuk iuran keikutsertaan, maka tidak diperbolehkan, karena hal itu merupakan pengambilan ongkos untuk suatu jaminan.

\section{a. Kartu Kredit ${ }^{18}$}

\section{Pertanyaan:}

Saya mempunyai kartu bank yang disebut dengan 'kartu kredit'. Melalui keanggotaan ini saya bisa membeli setiap kebutuhan yang saya perlukan, khususnya ketika dalam perjalanan dimana saya sangat antusias untuk tidak menggunakan uang, karena untuk menjaga keamanan dari pencurian dan kehilangan. Mengingat, keanggotaan pada kartu ini mewajibkan saya untuk membayar tagihan tahunan. Dalam hal ini, bank dimana saya berlangganan mengirimkan daftar bulanan bagi barang yang

\footnotetext{
${ }^{18}$ Khalid Al-Juraisiy, Fatwa-fatwa Terkini 2, Jakarta: Darul Haq, 2004, h. 90
} 
telah dibeli tanpa mengenakan biaya tambahan. Hanya saja, dalam kondisi saya tidak melunasi tagihan bulanan, maka dikenakan bunga atas hal itu. Perlu duketahui, bahwa saya tidak akan terlambat dalam membayar tagihan karena biayanya terpenuhi (ada). Apa hukum kartu tersebut?

\section{Jawaban:}

Dalam pandangan saya, tidak boleh berlangganan pada kartu seperti ini karena adanya tagihan tahunan diambil dari para anggota. Disamping itu, karena hal itu membuat anda dibatasi untuk tidak membeli kecuali dari orang-orang tertentu saja, atau bila anda terlambat melunasinya, maka bank tersebut akan menambah biaya bagi anda, dan tambahan biaya ini tidak lain adalah riba yang kentara, akan tetapi bila anda takut terjadi pencurian terhadap uang anda dalam kondisi perjalanan, maka mungkin dibolehkan menggunakan kartu tersebut sesuai ukuran keperluannya saja.

\section{b. Kartu Diskon ${ }^{19}$}

\section{Pertanyaan:}

Apa hukum pengunaan kartu diskon yang diterbitkan oleh sebagian perusahaan dengan biaya yang ringan? Kami mohon yang mulia menjawab seputar kriteria dari kartu seperti ini.

\section{Jawaban:}

Saya melihat bahwa kartu-kartu semacam ini hanyalah bentuk promosi suatu perusahaan untuk mendapatkan biaya-biaya tersebut dari para anggota. Demikian pula, biaya yang dibayar kepada mereka oleh toko-toko penjualan bahan makanan dan perbekalan serta pasar-pasar yang mereka tunjuk. Kemudian juga, hal tersebut dapat membahayakan (merugikan) sebagian penyewa kios-kios dagang di pasar yang tidak bergabung menjadi anggota perusahaan tersebut karena para konsumen akan lari dari mereka karena adanya diskon semu tersebut.

Karenanya, saya berpendapat harus menjauhi (menghindari) diskondiskon tersebut, wallahu a'lam.

\footnotetext{
${ }^{19}$ Khalid Al-Juraisiy, Fatwa-fatwa Terkini 2, Jakarta: Darul Haq, 2004, h. 90
} 


\section{c. Kartu 'Visa' Bank ${ }^{20}$}

\section{Pertanyaan:}

Fadhilatusy Syaikh, yang mulia, dewasa ini terdapat apa yang dinamakan dengan 'Kartu Visa' jenis Emas dan Perak yang dikeluarkan oleh sebagian bank. Kartu ini memiliki nilai seharga antara 350 hingga 450 Riyal pertahun, baik dengan cara memnjam di bank ataupun tidak. Dia memberi batasan harga pada anda tidak boleh lebih dari 20.000 Riyal, anda tetap memiliki jumlah tersebut selama 21 hari tanpa bunga, sebagaimana mereka sebutkan. Dan setelah itu, mulailah diberi bunga. Kami benar-benar bingung masalah ini. Karenanya, kami mohon yang mulia menjelaskan hukum syari'atnya tentang hal ini, semoga Allah menjaga anda.

\section{Jawaban:}

Akad dengan kriteria seperti itu tidak boleh hukumnya karena mengandung riba, yaitu harga (nilai tukar) visa tersebut dan arti komitmen terhadap riba bila pelunasannya terlambat.

\section{d. Kartu Visa "Samba"21 \\ Pertanyaan:}

Telah beredar kartu (visa) "Samba" di tengah-tengah masyarakat yang dikeluarkan oleh bank Saudi-Amerika. Jika gold (emas), dikenakan biaya kartu 485 riyal, dan jika silver dikenakan biaya 245 riyal. Biaya ini dibayar tahunan kepada bank oleh pemegang kartu visa atas manfaat yang telah diperolehnya dari kartu tersebut sebagai iuran tahunan.

Cara penggunaan kartu ini adalah sebagai berikut: pemegang kartu dapat menggunakan kartu ini untuk menarik dana (pinjaman) yang dikehendakinya dari cabang bank mana saja, dan dia harus melunasi pinjaman tersebut selama masa yang tidak boleh melebihi 45 hari. Jika dia belum melunasi dana (pinjaman) yang ditariknya tersebut selama masa yang disebutkan di atas, maka pihak bank akan mengenakan setiap 100 riyal dari pinjaman dana yang ditarik tersebut suku bunga yang nilainya 1,95 (1 riyal 95 halalah), sebagaimana bank akan mengambil setiap penarikan tunai bagi

${ }^{20}$ Khalid Al-Juraisiy, Fatwa-fatwa Terkini 2, Jakarta: Darul Haq, 2004, h. 92

${ }^{21}$ Ahmad bin 'Abdurrazzaq ad-Duwaisy, Fatwa-fatwa Jual Beli oleh Ulama-ulama Besar Terkemuka, (Bogor: Pustaka Imam Syafi'I, 2004), h. 537 
pemegang kartu 3,5 riyal dari setiap 100 riyal yang diambil dari bank. Atau mereka akan mengambil 45 riyal sebagai batas minimal dari setiap proses penarikan tunai.

Selain itu, pemegang kartu ini juga bisa berbelanja berbagai macam barang dari tempat-tempat perbelanjaan yang sudah bekerjasama dengan pihak bank, tanpa harus membayar uang tunai. Dan pembayaran tagihan belanja itu menjadi pinjaman baginya pada pihak bank. Namun, jika dia terlambat membayar jumlah tagihan penggunaan belanja itu dari waktu 45 hari yang telah ditentukan, maka pihak bank akan mengenakan bunga kepada pemegang kartu pada setiaqp 100 riyal dari nilai barang belanjaan yang dibeli dari tempat-tempat perbelanjaan yang bekerjasama dengan bank dengan suku bunga yang nilainya 1,95 (1 riyal 95 halalah)

Lalu bagaimana hukum pengunaan kartu ini dan keikutsertaan/ keanggotaan tahunan dengan bank ini dengan bisa memanfaatkan kartu ini?

Jawaban:

Jika keadaan kartu (Samba Visa) seperti yang disebutkan di atas, maka hal itu merupakan edisi baru dari para pelaku riba, sekaligus sebagai praktek memakan harta orang lain dengan cara pengotoran usaha yang tidak bear, juga merupakan tindak pencemaran dan pengotoran usaha dan mu'amalah mereka. Yang demikian itu tidak keluar dari riba Jahiliyyah yang diharamkan oleh syari'at yang suci. Hukum riba Jahiliyyah menyebutkan: «Kamu lunasi atau kamu harus menambahnya.» Oleh karena itu, tidak diperbolehkan menerbitkan kartu ini dan tidak boleh juga bermu’amalah dengannya.

\section{e. Kartu Gold dan Kartu Silver ${ }^{22}$}

\section{Pertanyaan:}

Saya sampaikan ke hadapan anda pertanyaan yang disampaikan kepada kami dari pegawai Pangkalan Angkatan Udara di Tabuk mengenai masalah agama. Mereka menginginkan jawaban anda atas pertanyaan tersebut, karena masalah ini banyak diperbincangkan dan dilakukan orang banyak.

22 Ahmad bin 'Abdurrazzaq ad-Duwaisy, Fatwa-fatwa Jual Beli oleh Ulama-ulama Besar Terkemuka, (Bogor: Pustaka Imam Syafi'I, 2004), h. 538 
Dan sehingga fatwa menjadi pemecah bagi banyak kesulitan. Pertanyaan tersebut sebagai berikut:

Bagaimana hukum kartu gold dan kartu silver? Yaitu kartu yang dijual bank kepada masyarakat sekalipun mereka tidak mempunyai rekening di bank tersebut. Manfaat dari kartu ini bagi pemegangnya adalah dia bisa meminjam sejumlah dana dari bank yang menjual ini kepadanya, dengan ketentuan dia harus mengembalikan dana yang dipinjamnya itu selama masa 45 hari dari tanggal pinjaman. Dan jika dia melakukan keterlambatan dari masa tersebut, maka bank akan memberlakukan suku bunga ringan sebagai denda keterlambatan. Semakin lama terlambat maka akan semakin bertambah pula tingkat suku bunga tersebut. Ada beberapa orang yang membeli lebih dari satu kartu, dengan cara dia mengambil pinjaman dari satu bank, dan sebelum akhir masa yang berikutnya, dia akan mengambil dari bank lain dan membayarnya ke bank ini. Demikianlah yang dia kerjakan sehingga dia tidak membayar denda keterlambatan. Lalu, bagaimana pendapat anda mengenai kedua hal di atas?

\section{Jawaban:}

Kartu silver atau kartu gold dengan syarat yang disebutkan di atas merupakan kartu yang syarat dengan riba, yang tidak boleh diterbitkan dan juga dimanfaatkan. Sebab, kartu ini mengandung pinjaman yang menarik keuntungan. Itu jelas riba yang diharamkan. Dan menggunakannya merupakan salah satu bentuk tolong-menolong untuk berbuat dosa dan pelanggaran.

\section{f. Kartu untuk Membayar Tagihan Belanja Barang dari Rekening Pem- beli ke Rekening Penjual Seketika itu juga. ${ }^{23}$}

\section{Pertanyaan:}

Kami mengharapakan kemurahan anda untuk memberitahu kami tentang penggunaan Kartu Jaringan Saudi untuk membeli beberapa kebutuhan dari tempat perbelanjaan yang prosesnya sebagai berikut: Setelah diketahui jumlah nilai pembelian, misalnya 150 riyal, pembeli akan mengeluarkan kartu kepada penjual untuk kemudian digesek dengan alat

${ }^{23}$ Ahmad bin 'Abdurrazzaq ad-Duwaisy, Fatwa-fatwa Jual Beli oleh Ulama-ulama Besar Terkemuka, (Bogor: Pustaka Imam Syafi'I, 2004), h. 539 
yang ada padanya. Kemudian jumlah tagihan pembelian itu akan dipotong melalui kartu tersebut, dan pada saat itu juga dana pembeli akan pindah dari rekening pembeli ke rekening penjual, yakni sebelum pembeli meninggalkan tempat.

\section{Jawaban:}

Jika masalahnya seperti yang disebutkan di atas, maka tidak ada larangan untuk menggunakan kartu tersebut, jika pembeli memiliki dana yang memadai untuk membayar tagihan pembelian.

\section{g. Hukum Proses Penjualan Melalui Jaringan Internet ${ }^{24}$ \\ Pertanyaan:}

Beberapa hari belakangan ini sering dilakukan proses penjualan melalui jaringan internet, apa hukumnya menurut syari'at? kami mohon diberi fatwa mengenai hal itu, semoga anda diganjar pahala oleh Allah.

\section{Jawaban:}

Di antara syarat-syarat penjualan adalah mengetahui harga dan mengetahui barang sehingga ketidaktahuan terhadap imbalan (harga) dan barang tersebut lenyap sebab ketidaktahuan ini dapat menimbulkan perbedaan dan perselisihan yang memiliki dampak yang luar biasa terhadap munculnya permusuhan antara sesama kaum muslimin, saling tidak berteguran, memutus silaturrahim dan saling membelakangi (tidak peduli) yang ke semua ini dilarang dan diperingatkan oleh Allah SWT.

Manakala mengetahui barang hanya bisa terealisir melalui proses melihat atau kriteria yang jelas, maka kami memandang bahwa hal tersebut tidak akan menjadi jelas kecuali dengan cara bertemu dan berbicara langsung, menyaksikan barang serta mengetahui manfaat dan jenisnya. Terkadang, hal itu tidak akan dapat terealisir dengan sempurna bilamana proses akad dilaksanakan melalui monitor atau pembicaraan via telepon yang biasanya sering terjadi pengabaian dalam menjelaskan dan berlebihlebihan dalam memuji produksi serta menyebutkan keungulan-keunggulan produknya tersebut sebagaimana yang tampak jelas dalam berbagai bentuk

${ }^{24}$ Khalid Al-Juraisiy, Fatwa-fatwa Terkini 2, Jakarta: Darul Haq, 2004, h. 96 
iklan dan promosi yang dipublikasikan melalui surat-surat kabar dan majalah-majalah padahal tidak terbukti atau kebanyakannya tidak terbukti ketika digunakan. Apapun alasannya, bila memang terealisasi syarat di dalam menjelaskan, mengetahui harga dan barang serta ketidaktahuan akan hal itu telah lenyap; maka boleh melakukan transaksi dan akad jual-beli melalui telepon, monitor, internet atau sarana-sarana lainnya yang memang dapat dimanfaatkan, menjamin dari kerusakan, manipulasi, merugikan kepentingan dan mendapatkan harta dengan cara yang tidak haq. Bila salah satu dari dampak-dampak negatif ini ada pada transaksi jual-beli tersebut, maka jual-beli dengan sarana-sarana tersebut tidak dibolehkan. Betapa banyak terjadi kerugian yang fatal dan kebangkrutan yang dialami oleh pemilik modal besar karena hal itu, belum lagi ditambah dengan terjadinya perselisihan dan perseteruan yang membuat sibuk para Qhadi dan Hakim dalam menyelesaikannya.

\section{h. Hukum Menjual dan Membeli saham-saham perusahaan melalui Jar- ingan Internet. ${ }^{25}$}

\section{Pertanyaan:}

Proses peredaran jual-beli saham-saham perusahaan bisnis sering dilakukan melalui jaringan internet, bagaimana hukumnya menurut syari'at?

\section{Jawaban:}

Perusahaan-perusahaan Islami hukumnya dibolehkan baik ia bergerak di bidang perdagangan, produksi, pertanian, konstruksi atau semisalnya. Para ulama fikih telah menyebutkan lima dari jenis syarikah tersebut, yaitu syarikah inan, syarikah Mudharabah, syarikah Abdan, syarikah wujuh dan syarikah Mufawadhah. Bilamana syarikah tersebut telah menaruh modalnya pada barang yang ditawarkan untuk dijual dan dibeli sedangkan barang-barang tersebut termasuk kategori barang yang dibolehkan bertransaksi dengan nya, maka menjual saham-sahamnya diperbolehkan bila modalnya diketahui dan jumlah saham yang dijual telah ditentukan. Jadi, boleh bagi si pemiliknya berkata kepada pembeli, "saya jual kepada anda bagian saya dari syarikah/perusahaan ini yang sebesar 1,5-nya, 0,1-nya, 0,4-nya, 0,01-nya atau semisalnya". Lalu si

\footnotetext{
${ }^{25}$ Khalid Al-Juraisiy, Fatwa-fatwa Terkini 2, Jakarta: Darul Haq, 2004, h. 97
} 
pembeli mengambil posisi si penjual, kapan saj syarikah tersebut membuka penjualan saham-sahamnya, dia bisa mengambil modal yang dimiliki oleh si penjual tersebut, berikut bagiannya dari keuntungan. Demikian juga hal seperti ini berlaku pada perusahaan-perusahaan yang bergerak di bidang produksi, bila si penjual tersebut menaruh modalnya pada peralatan-peralatan beratnya yang digunakan untuk memproduksi dan memasarkan produksi mereka, maka penanam saham boleh menjualnya baik seluruhnya ataupun sebagainya dengan harga yang diketahui, serahterimanya dilakukan di majlis akad atau kuitansinya telah dipegang sehingga tidak tidak jual beli hutang dengan hutang. Bila perusahaan memiliki stock modal, maka sebaiknya tidak menjualnya agar tidak terjadi agar tidak terjadi penjualan uang bersama barang dengan uang. Kecuali jika setoknya sedikit, maka juga termasuk ke dalam masalah tersebut sebagai sub-ordasinya.

Juga tidak apa-apa menjual saham-saham tersebut dengan peratara media komunikasi modern, seperti telepon dan internet bila ijab kabul (serah-terima)nya dapat terealisasi secara berturut-turut (teratur). Jika syarat berturut-turut kurang, kabul (penerimaan)nya menyalahi ijab, tidak diketahui berapa ukuran barang yang dijual, harga atau kuitansinya belum dipegang (disepakati) saat masih terjadi akad, atau saham-sahamnya ribawi seperti saham sebagian bank; maka penjualan seperti ini tidak boleh hukumnya, baik dilakukan via internet, secara lisan, via telepon atau selainnya.

\section{Penutup}

Dari uraian di atas, paling tidak ada dua faktor saling tarik menarik yang menjadikan itu pembaharuan dalam Islam—persisnya pembaharuan pemahaman tentang Islam-aktual sekaligus kontroversial sepanjang sejarah pemikiran Islam. Kedua faktor ini menurut M. Din Syamsudin bersifat intristik, melekat pada Islam itu sendiri, karenanya dapat dipandang sebagai watak-watak Islam. ${ }^{26}$

Pertama, Islam adalah agama yang universal, yang misinya adalah rahmat bagi semua penghuni alam, dalam arti cocok untuk segala ruang

${ }^{26}$ M. Din Syamsuddin, Mengapa Pembaharuan Islam? Dalam Jurnal Ulumul Qur'an no. 1, volume, tahun 1998 
dan waktu menuntut aktualisasi nilai-nilai Islam dalam konteks dinamika kebudayaan. Kontekstualisasi ini tidak lain dari upaya menemukan titik temu hakikat Islam dan semangat zaman.

Kedua, kemutlakan Islam sebagai agama terakhir yang memuat semua prinsip moral dan agama. Ini menunjukkan finalitas Islam sebagai wahyu Allah. Keyakinan finalitas fungsi kenabian menunjukkan tidak ada nabi setelah Nabi Muhammad, maka dapat dikatakan kontinuitas petunjuk agama wahyu diteruskan melalui para ulama mujaddid untuk memelihara dinamika ajaran Islam.

Konsep tentang universalitas Islam dan finalitas fungsi kenabian mendukung suatu ide bahwa tajdid (pembaharuan dan pemurnian) merupakan dimensi penting dalam sejarah kaum muslim, sehingga perlu kejelasan metodologi dalam memahami Islam dan persepsi tentang kedua konsep di atas.

Karena kita hidup di alam modern dan teknologi, adalah suatu hal yang niscaya untuk kembali kepada ajaran dasar atau kemurnian atau perbaikan (al-ashalah) Islam, tetapi harus didukung oleh kemajuan ilmu dan teknologi. Dengan kata lain, Islam berdasarkan kemurnian harus diterapkan dengan semangat zaman Inilah mungkin yang dimaksud dengan Islam sesuai dengan segala ruang waktu. Dimana kita mungkin saja kembali seperti zaman awal Islam, namun betapapun harus berhadapan dengan zaman jauh berbeda dengan awal Islam. Untuk itu diperlukan pembaharuan yang berdasarkan al-ashalah al-Islamiyah (Kemurnian ajaran Islam) yang beranjak dari dua landasan utama berupa al-Turats al-Islamiy (warisan Islam) dan al-Sunnan al-Nawamis (hukum alam dan hukum kehidupan ciptaan Allah).

Al-Turats al-Islamry yang terdiri dari al-Qur'an, as-Sunnah dan hasil ijtihad mujtahid harus dijembatani dengan al-Sunan al-Nawamis yang tak lain adalah hukum-hukum alam dan kehidupan yang tersingkap melalui ilmu pengetahuan yang kemudian dilakukan prioritas Islamisasi ilmu pengetahuan tersebut. Setelah dilakukan usaha ganda pemurnian terhadap sumber-sumber Islam Klasik dan ilmu pengetahuan modern, barulah masyarakat dapat diarahkan kepada tujuan penciptaannya bagi kebahagiaan semua makhluk Allah. Sehingga tercapailah cita-cita tajdid yang shalih li kulli zaman wa makan. 


\section{Pustaka Acuan}

Acmad jainuri, landasan Teologis Gerakan Pembaharuan Islam dalam Jurnal Ulumul Qur'an No. 3. Volume VI, tahun 1995

Ahmad bin 'Abdurrazzaq ad-Duwaisy, Fatwa-fatwa Jual Beli oleh Ulamaulama Besar Terkemuka, (Bogor: Pustaka Imam Syafi'I, 2004

Bustami Muhammad Sa'id, Gerakan Pembaharuan Agama Antara Modernisme dan Tajdiduddin, Bekasi PT. Wacanalazuardi, 1995

H.L. Beek dan N.J.G Kaptien (red), Pandangan Barat terhadap Literatun Hukum, Filosofot, Teologi, dan Mistik Tradisi Islam, Jakarta, INIS, 1998

Harun Nasution dan Azyumardi Azra, Perkembangan Modern Dalam islam, Jakarta: Obor, 1986

Harun Nasution, Pembaharuan dalam Islam Syarah Pemikiran dan Gerakan, Jakarta, Bulan Bintang, 1991, cet ke-8

Harun Nasution, Refleksi Pembaharuan Pemikiran Islam: 70 Tahun Harun Nasution, Jakarta, LSAF, pada bagian biografi Harun Nasution

John J. Donohue dan John L. Esposito. Islam dan Pembaharuan: Ensiklopedi Masalah-Maslah, Jakarta: PT. Rajawali Press, 1984

Khalid Al-Juraisiy, Fatwa-fatwa Terkini 2, Jakarta: Darul Haq, 2004

M. Din Syamsuddin, Mengapa Pembaharuan Islam? Dalam Jurnal Ulumul Qur'an no. 1, volume, tahun 1998

P.Sj. van Koningsvela, Naskah-Naskah Yunani tentang Bait al-Hikmah dan Kebijakan Khalifah al-Maimun dalam Herman Leonard Beek dan Niro Kaptein (Red) Studi Belanda Kontemporer tentang Islam, Jakarta: INIS, 1993

Rifyal Ka'bah, Modernisme dan Fundamentalisme ditinjau dari konteks islam, dalam Jurnal Ilmu dan Kebudayaan Ulumul Qur'an, No. 3, Volume VI, 1998

Yusran Asmuni, Pengantar Studi Pemikiran dan Gerakan Pembaharuan Dalam Dunia Islam, Jakarta PT. Rajagrafindo Persada, 1998, Cet. Ke-2 